УДК 796 (091) (477) (076)

doi: 10.15330/fcult.33.161-166

Тетяна Григоришина, Лариса Балацька

\title{
НАУКОВІ ПРІОРИТЕТИ ІСТОРИЧНОЇ ПАРАДИГМИ З ФІЗИЧНОЇ КУЛЬТУРИ І СПОРТУ УКРАЇНИ (за матеріалами дисертаційних робіт періоду (1939-1990 рр.))
}

\begin{abstract}
Мета. Визначення наукових пріоритетів історичної парадигми з фізичної культури $і$ спорту України в контексті наукової спадщини дисертащійних робіт (1939-1990 рр.). Матеріал. Автореферати дисертаційних робіт з історії фізичної культури і спорту, які репрезентовано до прилюдного захисту протягом I-го (1939-1965 рр.) та II-го (1966-1990 рр.) періодів. Методи: аналіз літератури $i$ джерел; синтез та аналогія; системно-структурний аналіз; контент-аналіз; проблемно-хронологічний; крос-культурний. Результати. Загальний кількісний показник виконання дисертаційних робіт становить 232, з них 9 - докторські. Кількість досліджень, націлених на висвітлення історії фізкультурної освіти і спорту на теренах Української РСР (радянський період) складає 14 робіт та становить $6 \%$. Змістові компоненти п'яти напрямів наукових досліджень з історї фізичної культури $i$ спорту зумовлено політичними, ідеологічними й сочіокультурними чинниками та методологію $i$ загальними тенденціями розвитку радянської історичної науки. Констатовано науковий нігілізм щуодо висвітлення питань з історії фізичної культури та спорту в дорадянський період украйнського та інших етносів, які мешкали на теренах, приєднаних до Української РСР в 1939, 1940 та 1945 рр. Зафіксовано недостатній ступінь розробки проблем з історії фізичної культури і спорту радянського періоду в Украӥнській РСР. Висновок. Визначено наукові пріоритети історичної парадигми з фізичної культури і спорту України, які характеризуються політичною заангажованістю $і$ тенденційністю та становлять певний етап формування системи наукових знань.
\end{abstract}

Ключові слова: наука, історична парадигма, фізична культура, спорт, Украӥна, 1939-1990.

Purpose. Study is to determine the dynamics and priorities of the historical paradigm of physical culture and sport of Ukraine in the context of the scientific heritage of dissertation papers that were presented to public protection during the period (1939-1990 years). Material. The scientific search was carried out on materials of 232 abstracts of dissertations on the history of physical culture and sports. The research problem is disclosed in the chronological periods of the first (1939-1965 years) and II (1966-1990 years) periods. Methods: systemstructural analysis; synthesis and analogy; content analysis; problem-chronological; cross-cultural. Results. There are five priority directions of historical research of the physical culture and sports. Quantitative and content components of these areas are determined by political, ideological and socio-cultural factors that determined the methodology and general trends of the development of contemporary historical science. We state the scientific nihilism of covering the issues of the history of physical culture and sport in the pre-Soviet period of the Ukrainian and other ethnic groups living in the territories annexed to the Ukrainian Soviet Socialist Republic in 1939 year, 1940 year and 1945 year. Insufficient degree of development of problems in the history of physical culture and sport in research has been established, aimed at the territorial boundaries of the then Ukrainian Soviet Socialist Republic. Conclusion: During the investigated period, the historical paradigm of physical culture and sport of Ukraine is characterized by political engagement and tenderness and is a certain stage in the formation of a system of scientific knowledge.

Key words: science, historical paradigm, physical culture, sport, Ukraine, 1939-1990.

Постановка проблеми й аналіз результатів останній досліджень. Історія фізичної культури і спорту - одна із профілюючих дисциплін в системі вищої фізкультурної освіти та один із напрямів наукових досліджень в сфері науки з фізичної культури і спорту [1]. Моніторинг наукової діяльності становить важливий компонент подальшого розвитку дослідницьких напрямів та спеціальностей. До проблеми каталогізації, методологічного аналізу та моніторингу дисертаційних робіт прикута увага провідних українських та зарубіжних вчених $[2,3,4]$. Окремі аспекти даної проблематики розкриті в наукових розробках наших співвітчизників $[5,6,7,8]$. Однак, визначенню динаміки та пріоритетів історичної парадигми 3 фізичної культури і спорту України в контексті наукової спадщини дисертаційних робіт, які репрезентовано до прилюдного захисту в період (1939-1990рр.), приділено недостатньо уваги. 
Система історичних наукових знань України успадкувала теоретичні та методологічні проблеми радянської науки з історії фізичної культури і спорту [8]. Вважаємо, що актуальним завданням сучасної історичної науки в Україні постає аналіз та систематизація дисертаційних робіт, захищених в період радянської доби та висвітлення невирішених або некоректно розкритих проблем історії фізичної культури і спорту нашої держави.

Мета дослідження - визначення пріоритетів історичної парадигми 3 фізичної культури і спорту України в контексті наукової спадщини дисертаційних робіт, які репрезентовано до прилюдного захисту в період (1939-1990рр.).

Методи й організація дослідження. Дослідження проводилось за використанням таких методів: аналіз літератури і джерел; синтез та аналогія; системно-структурний аналіз; контент-аналіз; проблемно-хронологічний; крос-культурний. Науковий пошук здійснено за матеріалами авторефератів дисертацій з історії фізичної культури і спорту. Проблематику дослідження розкрито в хронологічних рамках І-го (19391965 рр.) та II-го (1966-1990 рр.) періодів.

Результати і дискусія. Вихідний рубіж І-го періоду зумовлений оприлюдненням першої кандидатської дисертації з історії фізичної культури за авторством Ф.І. Самоукова (1939р.). Вихідний рубіж II-го періоду визначений першою докторською дисертацією з історії фізичної культури за авторством М.I. Пономарева (1966 р.).

Верхня хронологічна рамка нашого дослідження окреслена 1990 р., що зумовлено періодом розпаду СРСР та проголошенням у 1991 р. Незалежності України. Використовуючи поняття "радянський період" ми послуговуємося такими хронологічними рамками: (1923-1990 рр.) із врахуванням хронології приєднання до радянської держави та Української РСР окремих територій в 1939, 1940 та 1945 рр. Територіальна націленість наших наукових пошуків в аспекті розгляду історії фізичної культури етнічних спільнот Української РСР охоплює Україну згідно її сучасних державних кордонів.

Наукова спадщина дисертаційних робіт періоду радянської доби проаналізована в системі нижчеперелічених історичних напрямів досліджень.

1. Всесвітня фізична культура і спорт (ВФК і С). У даному напрямі узагальнено дисертаційні роботи, в яких розкрито розвиток фізичної культури і спорту за територіальними межами СРСР на різних етапах історичного поступу за періодизацією, встановленою радянською історичною наукою.

2. Фізкультурна освіта і спорт (ФО і С) народів СРСР (дорадянський період). Даний напрям об’єднує наукові дослідження, які націлені на висвітлення етнічних традицій фізкультурної освіти та спорту населення СРСР у дорадянський період.

3. Фізкультурна освіта і спорт (ФО і С) в республіках СРСР (радянський період). Даний напрям узагальнює дослідження, в яких розкрито проблематику в контексті територіальних меж республік радянської держави в період радянської доби.

4. Фізкультурна освіта і спорт (ФО і С) в СРСР - націленість досліджень на висвітлення історії фізкультурної освіти і спорту в радянській державі в цілому.

Ключове поняття визначених нами історичних напрямів досліджень зазначено як “фізкультурна освіта” [9]. Вважаємо, що “фізкультурна освіта” в контексті категорій “фізична культура" та “освіта" містить такі складові: 1) здобуття спеціальних знань, умінь і навичок у сфері фізичної культури; 2) формування на цій основі світогляду та фізичного здоров'я; 3) готовність до повноцінної життєдіяльності та соціальної активності [10]. Дане поняття передбачає й розгляд вищої фізкультурної освіти (підготовка педагогів галузі фізичної культури і спорту).

5. Міжнародний спортивний та олімпійський рух (MC і ОР). При розгляді досліджень даної групи ми дотримувались тлумачення змісту категорій “спортивний рух" 
[11] та “олімпійський рух" [12]. Зауважимо, що "Міжнародний спортивний рух" (МСР) поняття більш широке ніж поняття "Міжнародний олімпійський рух" (МОР). МСР осягає МОР, друге відноситься до першого як частка до цілого [5]. Отже, даний напрям узагальнюе дисертаційні роботи, в яких висвітлено історію як Міжнародного спортивного, так і олімпійського руху.

Результати аналізу змісту та констатація кількісних показників дисертаційних робіт з історії фізичної культури і спорту І-го періоду (1939-1965рр.) репрезентовано на (рис. 1) [1]. Верхній графік відображує загальну динаміку досліджень, а нижній націленість досліджень на терени Української РСР.

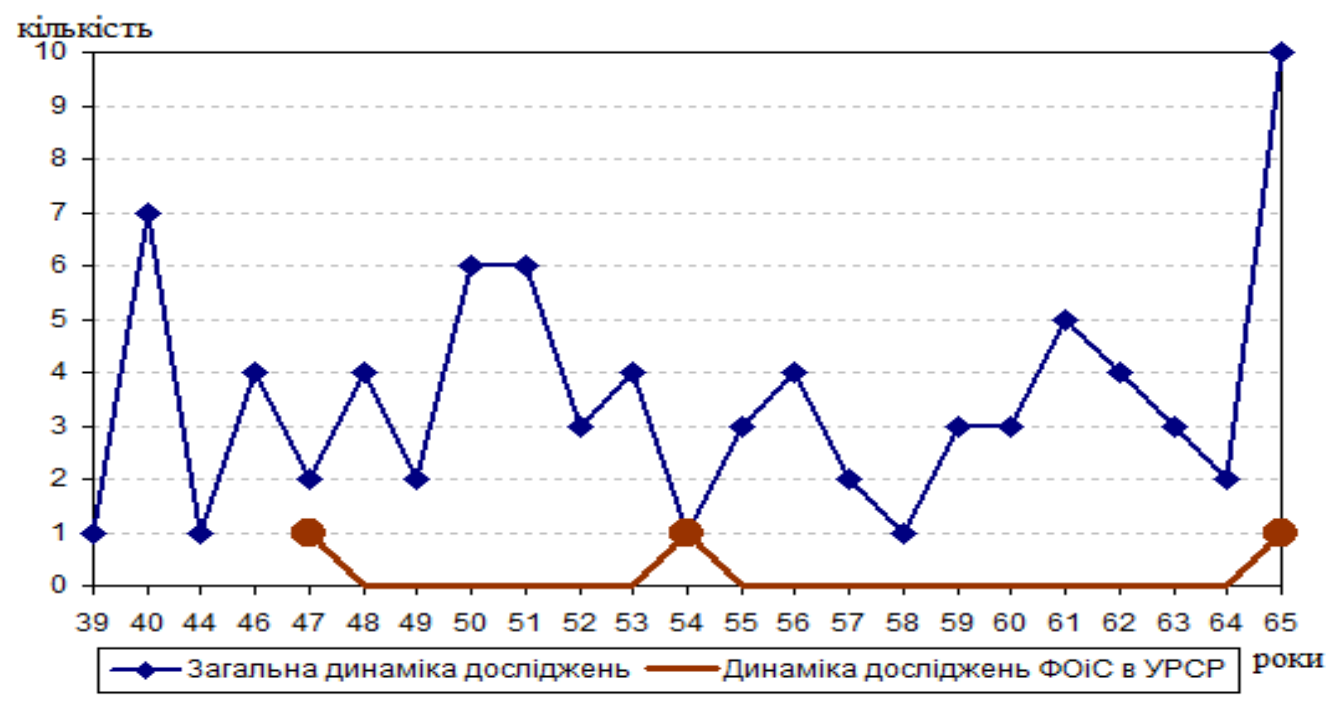

Рис. 1. Динаміка виконання дисертаційних робіт за період (1939-1965рр.)

Загалом, протягом І-го періоду виконано 81 кандидатська дисертація. Низькі кількісні показники виявлено у 1944, 1954, 1958 рр. - 1 дисертація, середній показник відзначений у 1940 р. - 7, високий кількісний показник зафіксовано у 1965 р. - 10.

Нами встановлено процентне співвідношення захищених дисертацій за історичними напрямами досліджень періоду (1939-1965 рр.).

Отже, за історичним напрямом ВФК і С виконано 5 дисертаційних робіт, що становить 6\%. Історію ФО і С народів СРСР (дорадянський період) розглянуто у 35 дослідженнях, що дорівнює 43\%. Історичний напрям ФО і С в республіках СРСР (радянський період) розкрито в 15 дисертаційних роботах, що становить 18,5\%. Три дисертації націлені на розгляд даної проблематики на теренах Української РСР, що становить 4\%. Напрям історії ФО і С в СРСР висвітлено в 19 дисертаціях, що становить 23,5\%. Історію МСР репрезентують 4 дослідження, що дорівнює 5\%.

Таким чином, історична парадигми науки з фізичної культури і спорту протягом І-го періоду (1939-1965 рр.) характеризується такими особливостями: Всесвітня історія фізичної культури і спорту висвітлена тільки за період Давніх часів та Середньовіччя; досліджень з історії Міжнародного олімпійського руху не проводилось; відсутність досліджень за напрямом дорадянської історії фізкультурної освіти українського та інших етносів на територіях, приєднаних до УРСР у 1939, 1940, 1945 роках; поверхневий розгляд аспектів фізкультурної освіти і спорту на теренах УРСР.

Динаміка виконання дисертаційних робіт з історії фізичної культури і спорту II-го періоду (1966-1990 рр.) репрезентовано на (рис. 2) [1]. Верхній графік віддзеркалює 
загальну динаміку розвитку наукової парадигми з історії фізичної культури і спорту, а нижній - націленість досліджень на терени Української РСР.

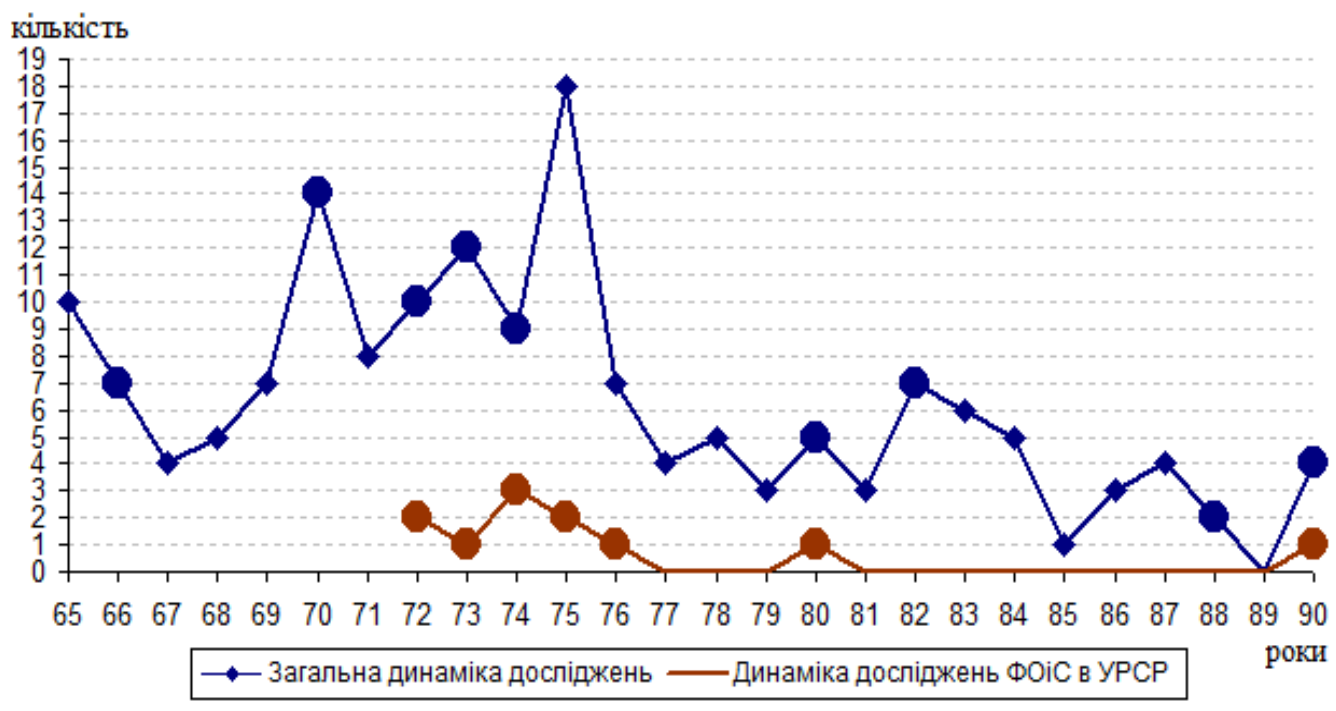

Puc. 2. Динаміка виконання дисертаційних робіт за період (1966-1990рр.)

Загалом, протягом досліджуваного періоду захищено 151 дисертаційна робота. Низькі кількісні показники зафіксовано у нижчезазначених роках: 1985 - (1); 1988 - (2); 1979, 1981, 1986 - (по 3). Значну кількість досліджень виявлено у таких роках: 1966, 1969, 1976, 1982 - (по 7); 1981 - (8); 1974 - (9); 1972 - (10); 1973 - (12); 1970 - (14). Високий кількісний показник виконання дисертаційних робіт показано у 1974 році - (18).

Нами визначено процентне співвідношення захищених дисертацій за історичними напрямами досліджень II-го періоду (1966 - 1990 рр.).

Отже, історію ВФК і С розкрито у 19 дисертаційних роботах, 3 них 4 - докторські, що становить 13\%. Проблеми історії ФО і С народів СРСР (дорадянський період) висвітлено у 13 дослідженнях, що складає 8\%. За історичним напрямом ФО і С в республіках СРСР (радянський період) виконано 56 дисертацій, з них - 1 докторська, що становить 37,5\%. Історію ФО і С в УРСР висвітлено в 11 дисертаційних роботах, що становить 7\%. За напрямом історія ФО і С в СРСР здійснено 34 дослідження, з них 4 докторські, що становить 22,5\%. Історію MC і ОР розкрито у 18 дослідженнях, що дорівнює $12 \%$.

Таким чином, протягом II-го періоду (1966 - 1990 рр.) виконано 151 дисертаційна робота, з них 9 - докторські. Визначено подвійний кількісний приріст досліджень за історичним напрямом "Всесвітня фізична культура і спорт". Встановлено значне зменшення (втричі) кількості досліджень з історії фізкультурної освіти і спорту народів СРСР у дорадянський період. Значний кількісний приріст досліджень (в три 3 половиною рази) відбувся за історичним напрямом "Фізкультурна освіта і спорт в республіках СРСР радянського періоду”. Зауважимо, що за даним напрямом виконано 11 досліджень, в яких територіально окреслена УРСР. Вдвічі збільшився кількісний показник виконаних дисертацій, в яких розкрито історію Міжнародного спортивного та олімпійського руху.

Висновки. Загальний кількісний показник виконання дисертаційних робіт, становить 232, з них 9 - докторські. Кількість досліджень, націлених на висвітлення історії фізкультурної освіти і спорту на теренах Української РСР (радянський період) складає 14 робіт і становить 6\%. Змістові компоненти п'яти напрямів наукових дослі- 
джень з історії фізичної культури і спорту зумовлено політичними, ідеологічними й соціокультурними чинниками та методологію і загальними тенденціями розвитку радянської історичної науки.

Констатовано науковий нігілізм щодо висвітлення питань 3 історії фізичної культури та спорту в дорадянський період українського та інших етносів, які мешкали на теренах, приєднаних до Української РСР в 1939, 1940 та 1945 рр. Зафіксовано недостатній ступінь розробки проблем з історії фізичної культури і спорту радянського періоду в Українській РСР. Визначено наукові пріоритети історичної парадигми 3 фізичної культури і спорту України, які характеризуються політичною заангажованістю і тенденційністю та становлять певний етап формування системи наукових знань.

Перспективи подальших наукових пошуків націлені на дослідження пріоритетів історичної парадигми 3 фізичної культури і спорту України в контексті наукової спадщини дисертаційних робіт, виконаних за період (1991-2019рр.).

1. Устінова ТБ. Генезис наукових знань з історії фізичної культури України. Педагогіка, психологія та медико-біологічні проблеми фізичного виховання і спорту [Інтернет]. 2013; (10): 78-2. Доступно: http://www.sportpedagogy.org.ua

2. Суник АБ. Очерки отечественной историографии истории физической культуры и спорта. Москва: Советский спорт; 2010. 616 с.

3. Суник АБ. Становление и развитие в СССР истории физической культуры как науки (1917 - середина 80-х годов) [дисертация]. Москва: ВНИИФК; 1988. 568 с.

4. Андрійчук ОЯ, Григус IM. Аналіз дисертаційних робіт з фізичного виховання та спорту за період 3 1998 по 2008 роки. Педагогіка, психологія та медико-біологічні проблеми фізичного виховання $\mathrm{i}$ спорту [Інтернет]. 2010; (2): 3-8. Доступно: http://www.sportpedagogy.org.ua

5. Устінова ТБ. Розвиток гімнастичного руху в контексті фізкультурної освіти країн Європи (друга половина XIX ст. - 30-ті pp. XX ст.). Теорія і методика фізичного виховання і спорту. Наук.-теорет. журнал НУФВСУ. 2012; (3): 134-8.

6. Єрмаков СС. Методологічний аналіз проблем дисертаційних досліджень. Філософія і сучасність. 2008; (1): 51-7.

7. Ермаков СС. Каталог: 500 авторефератов диссертаций по физическому воспитанию и спорту. Харьков: ХДАИ; 2002. 328 с.

8. Свістельник IP, Заневський IП. Характеристика інформаційного забезпечення вищої фізкультурної освіти. Педагогіка, психологія та медико-біологічні проблеми фізичного виховання і спорту [Інтернет]. 2006; (3): 141-4. Доступно: http://www.sportpedagogy.org.ua.

9. Круцевич ТЮ, редактор. Загальні основи теорії методики фізичного виховання. Київ: Олімпійська література; 2008. $391 \mathrm{c.}$

10. Устінова ТБ. Теоретико-методологічні основи досліджень з історії фізичної культури і спорту. Вісник ЧНПУ. Сер.: Пед. науки. Фіз. вих. і спорт. 2012; 1 (98): 255-8.

11. Матвеев ЛП. Основы общей теории спорта и системы подготовки спортсменов. Киев: Олимпийская литература; 1999. 317 с.

12. Платонов ВН., Гуськов СИ. Олимпийский спорт. Киев: Олимпийская литература; 1994. 496 с.

\section{References}

1. UstInova TB. Genezis naukovih znan z IstorIYi fIzichnoYi kulturi UkraYini. PedagogIka, psihologIya ta mediko-bIologIchnI problemi fIzichnogo vihovannya I sportu [Internet]. 2013; (10): 78-2.

13. Dostupno: http://www.sportpedagogy.org.ua.

2. Sunik AB. Ocherki otechestvennoy istoriografii istorii fizicheskoy kulturyi i sporta. Moskva: Sovetskiy sport; 2010. $616 \mathrm{~s}$.

3. Sunik AB. Stanovlenie i razvitie v SSSR istorii fizicheskoy kulturyi kak nauki (1917 - seredina 80-h godov) [disertatsiya]. Moskva: VNIIFK; 1988. 568 s.

4. AndrIychuk OYa, Grigus IM. Analiz disertatsiynih robit z fIzichnogo vihovannya ta sportu za period z 1998 po 2008 roki. PedagogIka, psihologIya ta mediko-biologichni problemi fizichnogo vihovannya i sportu [Internet]. 2010; (2): 3-8. Dostupno: http://www.sportpedagogy.org.ua.

5. UstInova TB. Rozvitok gImnastichnogo ruhu v kontekstI fIzkulturnoYi osvIti kraYin Evropi (druga polovina HIH st. - 30-tI rr. HH st.). Teorlya I metodika fIzichnogo vihovannya I sportu. Nauk.-teoret. zhurnal NUFVSU. 2012; (3): 134-8. 
6. Ermakov SS. Metodologichniy analiz problem disertatsiynih doslidzhen. Filosofiya i suchasnist. 2008; (1): 51-7.

7. Ermakov SS. Katalog: 500 avtoreferatov dissertatsiy po fizicheskomu vospitaniyu i sportu. Harkov: HDAI; 2002. $328 \mathrm{~s}$.

8. SvIstelnik IR, Zanevskiy IP. Harakteristika InformatsIynogo zabezpechennya vischoYi fIzkulturnoYi osvIti. PedagogIka, psihologIya ta mediko-bIologIchnI problemi fIzichnogo vihovannya I sportu [Internet]. 2006; (3): 141-4. Dostupno: http://www.sportpedagogy.org.ua.

9. Krutsevich TYu, redaktor. Zagalni osnovi teorii i metodiki fIzichnogo vihovannya. KiYiv: OlImpiyska literatura; 2008: 9.

10. UstInova TB. Teoretiko-metodologIchnI osnovi dosIIdzhen z IstorIYi fIzichnoYi kulturi I sportu. VIsnik ChNPU. Ser.: Ped. nauki. FIz. vih. I sport. 2012; 1 (98): 255-8.

11. Matveev LP. Osnovyi obschey teorii sporta i sistemyi podgotovki sportsmenov. Kiev: Olimpiyskaya literatura; $1999.317 \mathrm{~s}$.

12. Platonov VN., Guskov SI. Olimpiyskiy sport. Kiev: Olimpiyskaya literatura; 1994. 496 s.

\title{
Цитування на цю статтю:
}

Григоришина ТБ, Балацька ЛВ. Наукові пріоритети історичної парадигми з фізичної культури і спорту україни (за матеріалами дисертаційних робіт періоду (1939-1990рр.)). Вісник Прикарпатського університету. Серія: Фізична культура. 2019 Берез 26; 33: 161-166

\begin{tabular}{|c|c|}
\hline Відомості про автора: & Information about the author: \\
\hline $\begin{array}{l}\text { Григоришина Тетяна Борисівна - старший } \\
\text { викладач, Чернівецький національний університет } \\
\text { iмені Юрія Федьковича (Чернівці, Україна) }\end{array}$ & $\begin{array}{l}\text { Hryhoryshyna Tetiana Borysivna - lecturer, Yuriy } \\
\text { Fedkovych Chernivtsi National University (Cher- } \\
\text { nivtsi, Ukraina) }\end{array}$ \\
\hline \multicolumn{2}{|l|}{$\begin{array}{l}\text { e-mail: ustinova.tatyana@gmail.com } \\
\text { https://orcid.org/0000-0002-6888-0476 }\end{array}$} \\
\hline $\begin{array}{l}\text { Балацька Лариса Василівна - кандидат наук з фі- } \\
\text { зичного виховання і спорту, Чернівецький націо- } \\
\text { нальний університет імені Юрія Федьковича (Чер- } \\
\text { нівці, Україна) }\end{array}$ & $\begin{array}{l}\text { Balatska Larysa Vasylivna - Candidate of Science } \\
\text { (Physical Education and Sport), Yuriy Fedkovych } \\
\text { Chernivtsi National University (Chernivtsi, Ukraina) }\end{array}$ \\
\hline $\begin{array}{l}\text { e-mail: 1.-balatska@ukr.net } \\
\text { https://orcid.org/0000-0002-7963-2726 }\end{array}$ & \\
\hline
\end{tabular}

УДК 37.068

doi: 10.15330/fcult.33.166-171 Владислав Мочернюк

\section{ВОЛОНТЕРСЬКА ДІЯЛЬНІСТЬ СТУДЕНТІВ ФАКУЛЬТЕТУ ФІЗИЧНОГО ВИХОВАННЯІ СПОРТУ}

\begin{abstract}
Волонтерська діяльність набула значного розвитку в Україні і стала одним із реальних засобів підготовки фахівців у різних галузях, але наукового обгрунтування цієї діяльності недостатньо. У роботі представлені результати досліджень відношення студентів випускних курсів за кваліфікаційними рівнями бакалавра та магістра факультету фізичного виховання $і$ спорту.до волонтерської діяльності. Мета. Визначити напрямки волонтерської діяльності студентів спечіальності "Середня освіта (Фізична культура)”, відношення до неї та вплив на формування їхньої компетентності. Методи. Дослідження трунтувалося на застосуванні комплексу методів наукового пізнання: аналіз спеціальної літератури, документальних матеріалів, матеріалів мережі Інтернет; історико-логічний аналіз; структурно-функціональний аналіз; опитування; методи математичної статистики. Результати. Проаналізований досвід організації волонтерської діяльності студентів різних країн світу та зокрема тих, що навчаються на спеціальностях фізична культура і спорт. Визначені пріоритети студентів щуодо волонтерської діяльності та окремі аспекти нормативно-правового регулювання такої роботи. Серед студентів найбільше охочих займатися допомогою тваринам. Серед магістрів зростає частка готових займатись добровільною допомогою людям з особливими потребами, людям похилого віку, дітям, брати участь в організації різного роду спортивних заходів. В обох групах більшість готова займатись аналогічною діяльністю при умові оплати прачі і незначна кількість готова таку ж кількість часу працңювати безоплатно. Висновок. Студенти та магістри випускних курсів спеціальності
\end{abstract}

